\title{
Cytogenetic and molecular analysis of infertile Chinese men: karyotypic abnormalities, Y-chromosome microdeletions, and CAG and GGN repeat polymorphisms in the androgen receptor gene
}

T.T. Han, J. Ran, X.P. Ding, L.J. Li, L.Y. Zhang, Y.P. Zhang, S.S. Nie and L. Chen

Key Laboratory of Bio-Resources and Eco-Environment, Institute of Medical Genetics, Ministry of Education,

College of Life Science, Sichuan University, Chengdu, China

Corresponding author: T.T. Han / X.P. Ding

E-mail: han578388@gmail.com / brainding@scu.edu.cn

Genet. Mol. Res. 12 (3): 2215-2226 (2013)

Received December 21, 2012

Accepted March 12, 2013

Published July 8, 2013

DOI http://dx.doi.org/10.4238/2013.July.8.3

\begin{abstract}
Chromosome abnormalities, Y-chromosome microdeletions, and androgen receptor gene CAG and GGN repeat polymorphisms in infertile Chinese men featuring severe oligospermia and azoospermia were analyzed. Ninety-six fertile men and 189 non-obstructive infertile men, including 125 patients with azoospermia and 64 with severe oligozoospermia, were studied. Seventeen infertile men $(9.0 \%)$ carried a chromosome abnormality. Twenty (10.6\%) carried a Y-chromosome microdeletion. In the remainder of the patients and controls, GGN and CAG repeats were sequenced. Short GGN repeats $(\mathrm{n}<$ 23) appeared to be associated with defective spermatogenesis, with the number of GGN repeats strongly correlated with sperm counts. No significant difference in CAG repeats was found between patients and con-
\end{abstract}


trols, nor were CAG repeats correlated with sperm counts. However, for $\mathrm{CAG}$ repeats ranging between 24 and 25 , there was a $>2.5$-fold risk $(\mathrm{OR}=2.539,95 \% \mathrm{CI}=1.206-5.344, \mathrm{P}<0.05)$ of severe oligospermia and azoospermia. Our results confirmed the significant role of chromosome abnormalities, Y-chromosome microdeletions, and GGN repeats in Chinese male infertility.

Key words: Glutamine and glycine repeat polymorphisms; Karyotype; AZF microdeletions; Azoospermia; Non-obstructive oligospermia

\section{INTRODUCTION}

Infertility is defined as an inability to conceive or produce offspring after one year of regular sexual intercourse. It affects about $15 \%$ of couples worldwide and is on the rise. Approximately $40-50 \%$ of infertility may be attributed to male factors. Genetic factors including chromosomal aberrations and single gene mutations account for $10-15 \%$ of severe male infertility (Massart et al., 2012). Since their discovery by Tiepolo and Zuffardi in 1976, microdeletions in the long arm of the Y chromosome, namely the AZF regions, have been found in a substantial proportion of patients with non-obstructive spermatogenic failure, second only to Klinefelter syndrome. In contrast, $60-75 \%$ of male infertility remains idiopathic. Such patients usually present no family history and have normal findings on physical examination.

Recent research has suggested that idiopathic infertility may be caused in part by mutations or alterations in genes involved in spermatogenesis (Massart et al., 2012). Mutations of the androgen receptor (AR), located on X chromosome, can cause a variety of disorders including androgen insensitivity syndrome and complete androgen insensitivity syndrome. Since androgen activity is mediated by AR, gene mutations have been proposed as a possible cause of impaired spermatogenesis. Two polymorphic sites in the first exon of the $A R$ gene are characterized by various numbers of CAG and GGC repeats, resulting in polyglutamine and polyglycine stretches of variable lengths in the $\mathrm{N}$-terminal transcriptional activation domain of the AR protein that seem to modulate AR function (Ferlin et al., 2004). It is well known that expansion of the polyglutamine tract in men can lead to spinal bulbar muscular atrophy or Kennedy's disease, a fatal neuromuscular disease associated with low virilization, oligospermia and azoospermia, testicular atrophy, and reduced fertility. On the other hand, shorter AR polyglutamine stretches, and thus a more transcriptionally active AR, have been associated with increased risk of prostate cancer (Giovannucci et al., 1997). According to in vitro studies, AR alleles with 15,20, and $31 \mathrm{CAG}$ repeats are inversely correlated with transactivation capacity (Tut et al., 1997). This is consistent with the finding that CAG repeat length is correlated with sperm count in normal men (von Eckardstein et al., 2001). However, the functional consequences of GGN repeat variations remain unclear. Since genetic mutations may be transmitted to the next generation via artificial reproduction techniques like intracytoplasmic sperm injection (ICSI) and in vitro fertilization techniques, it is necessary to identify them prior to performing such procedures.

Only one study has described CAG polymorphisms in infertile Hong Kong Chinese men and no study has described GGN polymorphisms in infertile Chinese men. Our study therefore provides data for different ethnic backgrounds. We analyzed chromosome abnor- 
malities, Y-chromosome microdeletion, and $A R$ gene CAG and GGN repeat polymorphisms, and their correlation with male infertility in non-obstructive infertile Chinese men with severe oligozoospermia and azoospermia.

\section{MATERIAL AND METHODS}

\section{Subjects}

A total of 189 infertile Chinese men with confirmed non-obstructive infertility were recruited from the Affiliate Hospital of Sichuan Reproductive Health Research Center between 2009 and 2011, including 125 patients (age 20-53, mean 30 years) with azoospermia and 64 with severe oligozoospermia (sperm count $<5 \times 10^{6} / \mathrm{mL}$ ). The control group consisted of 96 Chinese men (age 20-35, mean 30 years) with normal sperm count and proven fertility, i.e., having at least one child by natural conception and one normal woman. All subjects in the experimental and control groups were Han Chinese from southwest China and all female partners were normal. All sperm samples were analyzed at least twice according to WHO 1999 guidelines. Informed consent was obtained from all participants.

\section{Cytogenetic analysis}

Chromosomal analysis was carried out with phytohemagglutinin-stimulated peripheral blood lymphocytes based on Giemsa-banding. Twenty metaphase spreads were analyzed for each slide. If a chromosomal abnormality was suspected, 50 more cells were counted. Abnormal karyotypes were evaluated according to the criteria established by the International System for Human Cytogenetic Nomenclature.

\section{DNA isolation}

Approximately $2 \mathrm{~mL}$ venous peripheral blood samples was collected. Genomic DNA was isolated with a Genomic DNA Purification Kit (Axgen, Hangzhou, China) according to manufacturer protocols.

\section{Y-chromosome microdeletion analysis}

Y-chromosome microdeletions were detected by PCR-amplifying specific sequence tag sites (STS). Fifteen pairs of primers were used (Table 1), including AZFa (SY84, SY86), AZFb (SY127, SY134, SY121, SY124, SY133), AZFc (SY254, SY255, SY157, SY242, SY277), and AZFd (SY145, SY152, SY153). An STS for the SRY gene, SY14, was used as a positive internal control. According to Simoni et al. (2004), DNA samples from a man with normal spermatogenesis and a woman were used as external positive and negative controls. The purpose of this was to maintain sensitivity and specificity, as well as to detect potential contamination.

Multiplex PCR amplifications were performed in a $25-\mu \mathrm{L}$ reaction system containing 50-100 ng genomic DNA, 1X amplification buffer $\left(\mathrm{Mg}^{2+}\right.$ free), $200 \mu \mathrm{M}$ dNTPs, 2-10 pmol of each primer, $1 \mathrm{U}$ Taq polymerase (Takara, Dalian), and $1.5 \mathrm{mM} \mathrm{Mg}^{2+}$ on a thermal cycler. The cycling conditions were as follows: initial denaturation at $94^{\circ} \mathrm{C}$ for $3 \mathrm{~min}, 35$ cycles of $30 \mathrm{~s}$ at 
$94^{\circ} \mathrm{C}, 30 \mathrm{~s}$ at $59^{\circ} \mathrm{C}$, and $30 \mathrm{~s}$ at $72^{\circ} \mathrm{C}$, with a final cycle at $72^{\circ} \mathrm{C}$ for $10 \mathrm{~min}$. The PCR product was stored at $4^{\circ} \mathrm{C}$ before electrophoresis.

\begin{tabular}{|c|c|c|c|c|}
\hline Multiplex PCR set & STS & Region & Primer sequence & Size (bp) \\
\hline \multirow[t]{4}{*}{1} & SY14 & SRY & $\begin{array}{l}\text { Forward: 5'-GAATATTCCCGCTCTCCGGA-3' } \\
\text { Reverse: 5'-GCTGGTGCTCCATTCTTGAG-3' }\end{array}$ & 472 \\
\hline & SY157 & $\mathrm{AZFc}$ & $\begin{array}{l}\text { Forward: 5'-CTTAGGAAAAAGTGAAGCCG-3' } \\
\text { Reverse: 5'-CCTGCTGTCAGCAAGATACA-3' }\end{array}$ & 286 \\
\hline & SY133 & $\mathrm{AZFb}$ & $\begin{array}{l}\text { Forward: 5'-ATTTCTCTGCCCTTCACCAGGA-3' } \\
\text { Reverse: 5'-TGATGATTGCCTAAAGGGAATTCA-3' }\end{array}$ & 177 \\
\hline & SY255 & $\mathrm{AZFc}$ & $\begin{array}{l}\text { Forward: 5'-GTTACAGGATTCGGCGTGAT-3' } \\
\text { Reverse: 5'-CTCGTCATGTGCAGCCAC-3' }\end{array}$ & 123 \\
\hline \multirow[t]{4}{*}{2} & SY14 & & & \\
\hline & SY277 & $\mathrm{AZFc}$ & $\begin{array}{l}\text { Forward: 5'-GGGTTTTGCCTGCATACGTAATTA-3' } \\
\text { Reverse: 5'-CCTAAAAGCAATTCTAAACCTCCA-3' }\end{array}$ & 312 \\
\hline & SY121 & $\mathrm{AZFb}$ & $\begin{array}{l}\text { Forward: 5'-AGTTCACAGAATGGAGCCTG-3' } \\
\text { Reverse: 5'-CCTGTGACTCCAGTTTGGTC-3' }\end{array}$ & 190 \\
\hline & SY124 & $\mathrm{AZFb}$ & $\begin{array}{l}\text { Forward: 5'-CAGGCAGGACAGCTTAAAAG-3' } \\
\text { Reverse: 5'-ACTGTGGCAAAGTTGCTTTC-3' }\end{array}$ & 109 \\
\hline \multirow[t]{4}{*}{3} & SY14 & & & \\
\hline & SY86 & AZFa & $\begin{array}{l}\text { Forward: 5'-GTGACACACAGACTATGCTTC-3' } \\
\text { Reverse: 5'-ACACACAGAGGGACAACCCT-3' }\end{array}$ & 320 \\
\hline & SY242 & $\mathrm{AZFc}$ & $\begin{array}{l}\text { Forward: 5'-ACACAGTAGCAGCGGGAGTT-3' } \\
\text { Reverse: 5'-TCTGCCACTAAACTGTAAGCTCC-3' }\end{array}$ & 233 \\
\hline & SY152 & AZFd & $\begin{array}{l}\text { Forward: 5'-AAGACAGTCTGCCATGTTTCA-3' } \\
\text { Reverse: 5'-ACAGGAGGGTACTTAGCAGT-3' }\end{array}$ & 125 \\
\hline \multirow[t]{4}{*}{4} & SY14 & & & \\
\hline & SY84 & $\mathrm{AZFa}$ & $\begin{array}{l}\text { Forward: 5'-AGAAGGGTCTGAAAGCAGGT-3' } \\
\text { Reverse: 5'-GCCTACTACCTGGAGGCTTC-3' }\end{array}$ & 326 \\
\hline & SY127 & $\mathrm{AZFc}$ & $\begin{array}{l}\text { Forward: 5'-GGCTCACAAACGAAAAGAAA-3' } \\
\text { Reverse: 5'-CTGCAGGCAGTAATAAGGGA-3' }\end{array}$ & 274 \\
\hline & SY153 & AZFd & $\begin{array}{l}\text { Forward: 5'-GCATCCTCATTTTATGTCCA-3' } \\
\text { Reverse: 5'-CAACCCAAAAGCACTGAGTA-3' }\end{array}$ & 139 \\
\hline \multirow[t]{3}{*}{5} & $\begin{array}{l}\text { SY14 } \\
\text { SY254 }\end{array}$ & $\mathrm{AZFc}$ & $\begin{array}{l}\text { Forward: 5'-GGGTGTTACCAGAAGGCAAA-3' } \\
\text { Reverse 5'-GA }\end{array}$ & 380 \\
\hline & SY134 & $\mathrm{AZFb}$ & $\begin{array}{l}\text { Forward: 5'-GTCTGCCTCACCATAAAACG-3' } \\
\text { Reverse: 5'-ACCACTGCCAAAACTTTCAA-3' }\end{array}$ & 301 \\
\hline & SY145 & AZFd & $\begin{array}{l}\text { Forward: 5'-CAACACAAAAACACTCATATACTC-3' } \\
\text { Reverse: 5'-TTGAGAATAATTGTATGTTACGGG-3' }\end{array}$ & 160 \\
\hline
\end{tabular}

PCR products $(5 \mu \mathrm{L})$ and $1 \mu \mathrm{L} 6 \mathrm{X}$ loading buffer were separated on a $2 \%(\mathrm{w} / \mathrm{v})$ agarose gel containing GoldView in 1X Tris-acetate EDTA at $90 \mathrm{~V}$ for $30 \mathrm{~min}$. A 50-bp DNA Ladder Marker was run to confirm product sizes. Results were visualized and recorded. Deletions were confirmed when the expected band was absent after 3 rounds of PCR and electrophoresis.

\section{CAG and GGN repeat polymorphisms}

Nested PCR and DNA sequencing were used to determine the length of the CAG and GGN repeat regions in exon 1 of the $A R$ gene. For CAG repeat analysis, a pair of oligonucleotide primers (5'-GTGCGCGAAGTGATCCAGAA-3' and 5'-TCTGGGACGCAACCTCTCT C-3') was selected for PCR amplification and a set of nested primers (5'-AGAGGCCGCGAGCG CAGCACCTC-3' and 5'-GCTGTGAAGGTTGCTGTTCCTCAT-3') was selected for DNA sequencing. Both reactions were performed under the same conditions (initiated with a 3-min denaturation step at $94^{\circ} \mathrm{C}$ and terminated with a 10 -min extension at $72^{\circ} \mathrm{C}$ ). Ampli- 
fication reaction profiles included denaturation at $94^{\circ} \mathrm{C}$ for $30 \mathrm{~s}$, annealing at $63^{\circ} \mathrm{C}$ for $30 \mathrm{~s}$, and extension at $72^{\circ} \mathrm{C}$ for $30 \mathrm{~s}$. For GGN repeat analysis, we used oligonucleotide primers 5'-TCGCATCAAGCTGGAGAACCCG-3' and 5'-ACCACACATCAGGTGCGGTGAAGTC3' for PCR amplification and nested primers 5'-CGCTTCCTCATCCTGGCACA-3' and 5'-CGGTGAAGTCGCTTTCCTGG-3' for DNA sequencing. Both reactions were performed under the same conditions (standard conditions with 5\% dimethylsulfoxide; initiated with a 5 -min denaturation step at $95^{\circ} \mathrm{C}$ and terminated with a 10 -min extension at $72^{\circ} \mathrm{C}$ ). Amplification profiles included denaturation at $95^{\circ} \mathrm{C}$ for $40 \mathrm{~s}$, annealing at $65^{\circ} \mathrm{C}$ for $30 \mathrm{~s}$, and extension at $72^{\circ} \mathrm{C}$ for $30 \mathrm{~s}$. The PCR products were sent to Invitrogen for DNA sequencing and sequence analyses were performed at the National Coalition Building Institute Web page (http://blast. ncbi.nlm.nih.gov/Blast.cgi).

\section{Statistical analysis}

Statistical analysis was performed in SPSS 13.0 for Windows (SPSS Inc., USA). Data were considered to be statistically significant when $\mathrm{P}<0.05$. The chi-square test was applied to detect differences in proportions between groups. The distribution of CAG and GGN repeats was compared with the Mann-Whitney U-test. To estimate relative risk between subsets of patients and controls, the odds ratio (OR) and 95\% confidence interval $(95 \% \mathrm{CI})$ were calculated based on the median CAG and GGN repeat lengths of the control group. Spearman's correlation coefficient was used for bivariate regression analysis to determine the correlation between CAG and GGN repeats and sperm count; OR and 95\%CI were calculated between azoospermic patients and those with sperm counts $<5 \times 10^{6} / \mathrm{mL}$.

\section{RESULTS}

\section{Chromosomal abnormality}

Karyotyping results are shown in Table 2 (285 infertile Chinese men, 125 with azoospermia and 64 with severe oligozoospermia; 96 fertile men with normal sperm count). Seventeen patients $(9.0 \%)$ had chromosome abnormalities, which accounted for $12.0 \%$ of the azoospermia and $3.7 \%$ of the oligozoospermia patients. This included 13 patients with Klinefelter syndrome (47,XXY; 12 azoospermic and 1 oligozoospermic). Three azoospermic patients had abnormal karyotypes (45,XO/46,XY; 46,XY, Y $\leq 21 ; 46, \mathrm{XX}$ male) accompanied by Y-chromosome microdeletions. The karyotype $46, \mathrm{XY}, \mathrm{t}(\mathrm{Xp} ; 16 \mathrm{q})$ was detected in an azoospermic patient. No chromosome abnormality was detected in the control group.

\section{Y-chromosome microdeletions}

As shown in Table 3, no AZF microdeletions were found in the controls. Of the 189 infertile men, $20(10.6 \%)$ were found to carry an AZF microdeletion. The frequencies of such microdeletions were $9.6 \%$ in azoospermia and $12.5 \%$ in oligozoospermia. The most common microdeletions were in AZFc (85\%), followed by AZFb (30\%), AZFa (20\%), and AZFd $(10 \%)$. One azoospermic patient with an abnormal karyotype (46,XX male) had deletions for all the STS excluding SY14 in the SRY gene. Deletions of STS SY254 and SY255 (75\%) were 
the most common, followed by SY157 and SY242 (55\%), SY134 (30\%), SY127 (25\%), SY86 (20\%), SY121 (15\%), and SY145 (10\%). The frequency of the remaining STS (SY84, SY133, SY124, SY277, SY152, SY153) was 5\%.

Table 2. Chromosomal abnormalities identified in patients with azoospermia and severe oligospermia.

\begin{tabular}{llc}
\hline Patient No. & Diagnosis & Chromosomal abnormality \\
\hline P 70 & Azoospermia & $47, \mathrm{XXY}$ \\
P 3 & Azoospermia & $47, \mathrm{XXY}$ \\
P 92 & Azoospermia & $47, \mathrm{XXY}$ \\
P 94 & Azoospermia & $47, \mathrm{XXY}$ \\
P 85 & Azoospermia & $47, \mathrm{XXY}$ \\
P 10 & Azoospermia & $47, \mathrm{XXY}$ \\
P 25 & Azoospermia & $47, \mathrm{XXY}$ \\
P 47 & Azoospermia & $47, \mathrm{XXY}$ \\
P 33 & Azoospermia & $47, \mathrm{XXY}$ \\
P 32 & Azoospermia & $47, \mathrm{XXY}$ \\
P 8 & Azoospermia & $47, \mathrm{XXY}$ \\
P 22 & Azoospermia & $47, \mathrm{XXY}$ \\
P 74 & Azoospermia & $45, \mathrm{XO} / 46, \mathrm{XY}$ \\
P 64 & Azoospermia & $46, \mathrm{XY}, \mathrm{Y} \leq 21$ \\
P 23 & Azoospermia & $46, \mathrm{XX}$ male \\
P 84 & Severe oligospermia & $47, \mathrm{XXY}$ \\
P 72 & Severe oligospermia & $46, \mathrm{XY}, \mathrm{t}(\mathrm{Xp} ; 16 \mathrm{q})$ \\
\hline
\end{tabular}

Table 3. Y-chromosome microdeletion detected in patients with azoospermia and severe oligospermia.

\begin{tabular}{lll}
\hline Patient No. & Diagnosis & STS of Y-chromosome microdeletion \\
\hline P 90 & Azoospermia & sY254, sY255 \\
P 1 & Azoospermia & sY86, sY254, sY255, sY157, sY242 \\
P 93 & Azoospermia & sY254, sY255 \\
P 39 & Azoospermia & sY86 \\
P 19 & Azoospermia & sY157 \\
P 17 & Azoospermia & sY86, sY254, sY255, sY157, sY242 \\
P 100 & Azoospermia & sY134 \\
P 21 & Azoospermia & sY134, sY127 \\
P 79 & Azoospermia & sY134, sY127, sY121, sY254, sY255, sY157, sY242, sY145 \\
P 74 & Azoospermia & sY134, sY127, sY254, sY255, sY157 \\
P 64 & Azoospermia & SY84, SY86, SY127, SY134, SY121, SY124, SY133, SY254, SY255, \\
P 23 & Azoospermia & SY157, SY242, SY277, SY145, SY152, SY153 \\
& sY254, sY255, sY157, sY242 \\
P 63 & Severe oligospermia & sY242 \\
P 98 & Severe oligospermia & sY254, sY255, sY157, sY242 \\
P 6 & Severe oligospermia & sY254, sY255, sY157, sY242 \\
P 11 & Severe oligospermia & sY254, sY255, sY157, sY242 \\
P 12 & Severe oligospermia & sY254, sY255 \\
P 30 & Severe oligospermia & sY254, sY255, sY242 \\
P 35 & Severe oligospermia & sY254, sY255 \\
P 99 & Severe oligospermia & \\
\hline
\end{tabular}

\section{CAG and GGN analysis of the $A R$ receptor gene}

For 101 azoospermic and 54 oligozoospermic patients with normal findings on chromosome and Y-chromosome microdeletion analysis, the CAG and GGN allele frequencies are summarized in Figures 1 and 2. The ranges and median values are shown in Table 4. By the Mann-Whitney U-test, GGN repeat lengths differed significantly between azoospermia, oligozoospermia, and control groups $(\mathrm{P}<0.05)$. As shown in Tables 5 and 6 , significantly more azo- 
ospermic and oligozoospermic patients had $<23$ GGN repeats $(\mathrm{P}<0.01)$. The OR was 2.450 for azoospermia $(95 \% \mathrm{CI}=1.329-4.517)$ and 5.396 for oligozoospermia $(95 \% \mathrm{CI}=2.615-11.133)$. No significant difference was found in CAG repeats or CAG repeats $>23$ between the patients and controls $(\mathrm{P}>0.05)$. Compared with the controls, the $\mathrm{OR}$ was 1.246 for azoospermia $(95 \% \mathrm{CI}=0.700-2.218)$ and 1.824 for oligozoospermia $(95 \% \mathrm{CI}=0.926-3.592)$. Spearman's correlation coefficient test indicated a correlation between GGN repeat length and sperm count in both patient groups $(\mathrm{P}<0.05)$. The $\mathrm{OR}$ for severe oligospermia is $2.202(95 \% \mathrm{CI}=1.118$ $4.339, \mathrm{P}<0.05$ ) versus azoospermia at GGN lengths $<23$. CAG repeat length was not significantly correlated with sperm count in the patient groups $(\mathrm{P}>0.05)$. However, for CAG repeat lengths $\geq 26$ and $<23$, the $\mathrm{OR}$ in azoospermia is $1.75(95 \% \mathrm{CI}=0.693-4.423)$ and $1.953(95 \% \mathrm{CI}$ $=0.993-3.843$ ) in comparison to severe oligospermia. As for CAG repeats of 24-25, the OR of severe oligospermia is $2.539(95 \% \mathrm{CI}=1.206-5.344, \mathrm{P}<0.05)$ versus the azoospermia group.

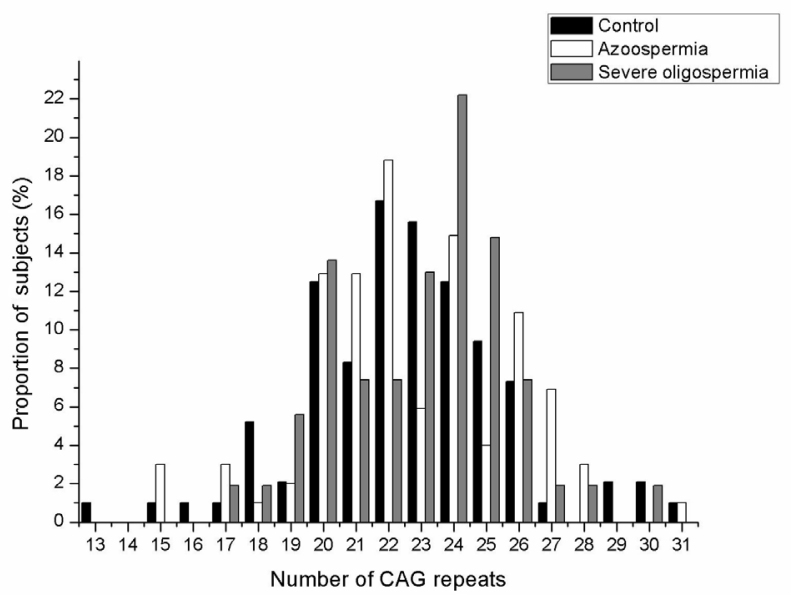

Figure 1. Distribution of CAG repeat lengths in infertile Chinese men and normal controls.

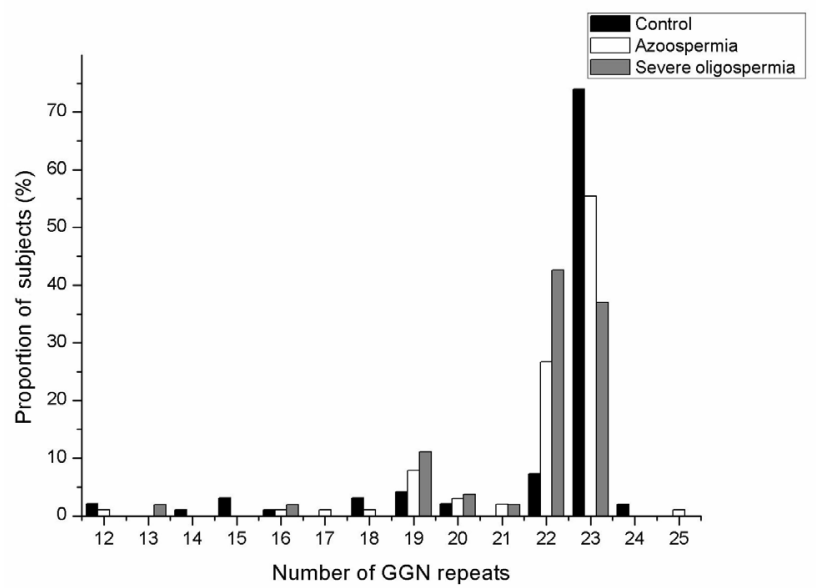

Figure 2. Distribution of GGN repeat lengths in infertile Chinese men and normal controls. 


\begin{tabular}{|c|c|c|c|c|c|c|}
\hline & \multicolumn{3}{|c|}{ CAG repeats } & \multicolumn{3}{|c|}{ GGN repeats } \\
\hline & Range & Means $\pm \mathrm{SD}$ & Median & Range & Means \pm SD & Median \\
\hline Controls $(\mathrm{N}=96)$ & $13-31$ & $22.5 \pm 3.0$ & 23 & $12-24$ & $21.9 \pm 2.5$ & 23 \\
\hline Azoospermia $(\mathrm{N}=101)$ & $15-31$ & $23.1 \pm 3.0$ & 23 & $12-25$ & $22.0 \pm 1.8$ & 23 \\
\hline Severe oligospermia $(\mathrm{N}=54)$ & $17-30$ & $23.1 \pm 2.5$ & 24 & $13-23$ & $21.7 \pm 1.9$ & 22 \\
\hline
\end{tabular}

$\mathrm{SD}=$ standard deviation.

Table 5. Distribution of CAG repeats $>23$ and GGN repeats $<23$ in infertile men and controls.

\begin{tabular}{|c|c|c|c|c|}
\hline & \multicolumn{2}{|c|}{$\mathrm{CAG}>23$} & \multicolumn{2}{|c|}{ GGN $<23$} \\
\hline & Patients & OR $(95 \% \mathrm{CI})$ & Patients & OR $(95 \% \mathrm{CI})$ \\
\hline Controls $(\mathrm{N}=96)$ & 34 & & 23 & \\
\hline Azoospermia $(\mathrm{N}=101)$ & 41 & $1.246(0.700-2.218)$ & $44 * *$ & $2.450(1.329-4.517)$ \\
\hline Severe oligospermia $(\mathrm{N}=54)$ & 27 & $1.824(0.926-3.592)$ & $34 * *$ & $5.396(2.615-11.133)$ \\
\hline
\end{tabular}

$* * \mathrm{P}<0.01$ vs controls (chi-square test). $\mathrm{OR}=$ odds ratio; $95 \% \mathrm{CI}=95 \%$ confidence interval.

Table 6. Distribution of CAG repeats $<23$, CAG repeats $\geq 26$, CAG repeats $=24$ and 25 , GGN repeats $<23$ in patients with azoospermia (A) and severe oligospermia ( $\mathrm{SO}$, sperm counts $<5 \times 10^{6}$ ).

\begin{tabular}{|c|c|c|c|c|c|c|c|c|}
\hline \multirow[t]{2}{*}{ Sperm counts } & \multicolumn{2}{|c|}{ CAG repeats $<23$} & \multicolumn{2}{|c|}{ CAG repeats $\geq 26$} & \multicolumn{2}{|c|}{ CAG repeats $=24$ and 25} & \multicolumn{2}{|c|}{ GGN repeat $<23$} \\
\hline & $\mathrm{N}$ & OR $(95 \% \mathrm{CI})$ & $\mathrm{N}$ & OR $(95 \% \mathrm{CI})$ & $\mathrm{N}$ & OR $(95 \% \mathrm{CI})$ & $\mathrm{N}$ & OR $(95 \% \mathrm{CI})$ \\
\hline $\begin{array}{l}\text { A } \\
\text { SO }\end{array}$ & $\begin{array}{l}54 \\
20\end{array}$ & $1.75(0.693-4.42)$ & $\begin{array}{r}22 \\
7\end{array}$ & $1.953(0.993-3.843)$ & $\begin{array}{l}19 \\
20^{*}\end{array}$ & $2.539(1.206-5.344)$ & $\begin{array}{l}44 \\
34 *\end{array}$ & $2.202(1.118-4.339)$ \\
\hline
\end{tabular}

$\mathrm{A}=$ sperm counts $=0 ; \mathrm{SO}=0<$ sperm counts $<5 \times 10^{6} . \mathrm{N}=$ number of patients. $\mathrm{OR}=$ odds ratio; $95 \% \mathrm{CI}=95 \%$ confidence interval. $* \mathrm{P}<0.05$.

\section{DISCUSSION}

The cause of male infertility is complex and genetic mutations play a significant role. Spermatogenesis is regulated by a number of genes located on various chromosomes and in the mitochondrial DNA (Poongothai et al., 2009). In this study, chromosome abnormalities, Y-chromosome microdeletions, and CAG and GGN repeat polymorphisms of the $A R$ receptor gene were analyzed. The incidence of chromosomal abnormality in azoospermic patients $(12.0 \%)$ was significantly higher than in oligozoospermic patients $(3.7 \%)$, although slightly lower than published data for azoospermic men (13.7-15.4\%) and similar to oligozoospermic men (1.76-4.6\%) (Van Assche et al., 1996). The most frequent sex chromosomal abnormality was Klinefelter syndrome (47,XXY), which can cause hypogonadism and infertility. Notably, this syndrome seems to affect patients with azoospermia and those with severe oligospermia. Only 2 similar patients with severe oligospermia have been reported (Crüger et al., 2001, 2003).

This study revealed that the prevalence of Y-chromosome microdeletions was $10.6 \%$ in infertile men, consistent with previous reports of 3 to $55 \%$ (Wang et al., 2010). The frequencies of AZF microdeletion in patients with azoospermia and severe oligospermia were 9.6 and $12.5 \%$, respectively, slightly higher than previously reported (Vutyavanich et al., 2007). This may be due to ethnic differences and the selection of STS markers. Deletion of AZFc was 
most common in patients with azoospermia as well as those with severe oligozoospermia, accounting for $85 \%$ of all AZF microdeletions in the present study. This is consistent with earlier studies, which showed that deletions are more frequent in the AZFc region than in the AZFa, $\mathrm{AZFb}$, and AZFd regions (Choi et al., 2004). However, it is unclear why the AZFc deletion is more frequent, although the DNA structure of this region may provide an explanation. AZFc is located in the distal Yq11, which is rich in repetitive DNA locks that frequently represent breakage hotspots. The repetitive sequences are closely related to unbalanced sister chromatid exchange and homologous recombination in the $\mathrm{Y}$ chromosome, and could give rise to Y-chromosome microdeletions. In addition, 8 patients with Y-chromosome microdeletion in the severe oligospermia group all incurred loss of AZFc, but in the azoospermia group without chromosome abnormality, deletions of AZFa, AZFb, and AZFc were detected. This was consistent with the previous conclusion that each AZF locus acts at a different phase of spermatogenesis, and deletion of each locus results in spermatogenic arrest at a particular stage (Viswambharan et al., 2007). AZFa deletions commonly result in complete Sertoli cell-only syndrome and azoospermia, while deletions of AZFb and AZFc are associated with a variable clinical and histological phenotype from Sertoli cell-only syndrome to oligozoospermia. AZFd deletions may present mild oligospermia or even normal sperm counts with abnormal sperm morphology such as severe teratozoospermia.

Although nearly $20 \%$ of infertile men with non-obstructive azoospermia and severe oligospermia may carry chromosomal abnormalities and Y-chromosome microdeletion, other factors may still be worthy of investigation. The CAG repeat polymorphisms of the $A R$ gene have been addressed in many studies. Previous studies on CAG repeats in infertile men have reported conflicting results. Some suggested no expansion (Dadze et al., 2000; Sasagawa et al., 2001; Van Golde et al., 2002; Rajpert-De Meyts et al., 2002; Lund et al., 2003; MartinezGarza et al., 2008; Badran et al., 2009), while others reported increased length (but still within the normal range) with respect to controls (Tut et al., 1997; Dowsing et al., 1999; Yoshida et al., 1999; Mifsud et al., 2001; Patrizio et al., 2001; Wallerand et al., 2001; Mengual et al., 2003; Katagiri et al., 2006). Only one study indicated that reduced CAG repeats are closely associated with impaired spermatogenesis in infertile men (Komori et al., 1999). These conflicting results may be attributed to varying ethnic backgrounds, as the stretches of CAG repeats appear to be longest in Asians, medium in whites, and shortest in Africans (Ferlin et al., 2004; Ackerman et al., 2012). Furthermore, this bias may also be related to limited sample sizes and inclusion criteria. However, few have studied the distribution of GGN repeat length among infertile and fertile men, and the functional consequences of GGN repeat variations remain unclear, even if deletion of the polyglycine tract reduces transcriptional activity of the $A R$ gene (Gao et al., 1996). Several epidemiological studies have suggested a significant, albeit modest, impact of the repeat on clinical androgenic effects, with the GGN repeat being associated with the risk of prostate cancer (Hakimi et al., 1997), alopecia (Hillmer et al., 2005), hypospadias (Aschim et al., 2004), and breast cancer (González et al., 2007). Previous studies have reported inconsistent results on GGN lengths in fertile men (Tut et al., 1997; Lund et al., 2003; Ferlin et al., 2004; Ruhaye et al., 2004; Castro-Nallar et al., 2010).

In this study, the distribution of CAG repeat length in the azoospermia and severe oligospermia groups did not significantly differ from the controls. These results were consistent with other studies in which no association was found (Dadze et al., 2000; Sasagawa et al., 2001; Van Golde et al., 2002; Rajpert-De Meyts et al., 2002; Lund et al., 2003; Martinez-Garza et al., 2008; 
Badran et al., 2009), but discordant with other studies that did find associations (Tut et al., 1997; Komori et al., 1999; Dowsing et al., 1999; Yoshida et al., 1999; Mifsud et al., 2001; Patrizio et al., 2001; Wallerand et al., 2001; Mengual et al., 2003; Katagiri et al., 2006). However, for CAG repeats $>23$, risks of $>1.2$-fold and $>1.8$-fold were found in azoospermia and severe oligospermia compared to the controls, although CAG repeat length was not significantly correlated with sperm counts in azoospermia and severe oligospermia. A $>2.5$-fold risk was found in severe oligospermia versus azoospermia with CAG repeats $=24-25$, while risks $>1.75$-fold and $>1.9$ fold were found in azoospermia versus severe oligospermia with CAG repeats $\geq 26$ and $<23$. In this study, shorter GGN repeat length was associated with defective spermatogenesis, consistent with findings in a Swedish population (Lundin et al., 2006), but discordant with other studies (Tut et al., 1997; Lundin et al., 2003; Ferlin et al., 2004; Ruhaye et al., 2004; Castro-Nallar et al., 2010). Moreover, $>2$.2-fold risk was associated with CGN repeats $<23$ in severe oligospermia versus azoospermia. In addition, the number of GGN repeats in the controls showed that GGN 23 was the only dominant allele. This was consistent with the previous study by Hsing et al. (2000) based on normal urban Shanghai Chinese men, but was not consistent with another group (Bogaert et al., 2009) who found that GGN 23 and 24 alleles were dominant, suggesting that conflicting results may be attributed to varying ethnic background and sample selection criteria.

The mechanism by which these alleles, although still in the normal range, seem to increase susceptibility for spermatogenic impairment remains unclear. We could speculate that CAG repeat lengths that vary to a certain extent (CAG repeats $\geq 26$ and CAG repeats $\leq 22$ ) are more likely to result in azoospermia than severe oligospermia. However, CAG repeat lengths of 24 and 25 were more likely to cause severe oligospermia than azoospermia. Furthermore, the decrease in GGN repeat length was more likely to cause severe oligospermia than azoospermia, and its role in spermatogenesis may be less substantial, because the number of severe oligospermia cases was greater with GGN repeats $<23$. In order to obtain more conclusive results, the relationship between male infertility and CAG and GGN polymorphisms requires further research, including in vitro transactivation studies.

With the introduction of testicular sperm extraction and ICSI, it is possible for patients with severely impaired spermatogenesis to pass on genetic mutations to their offspring. Therefore, it is important to offer genetic screening and counseling to infertile men prior to such procedures.

\section{Conflicts of interest}

We declare no competing financial interests with regard to the research described in the manuscript.

\section{ACKNOWLEDGMENTS}

We thank all patients who have participated in this study.

\section{REFERENCES}

Ackerman CM, Lowe LP, Lee H, Hayes MG, et al. (2012). Ethnic variation in allele distribution of the androgen receptor (AR) (CAG)n repeat. J. Androl. 33: 210-215.

Aschim EL, Nordenskjöld A, Giwercman A, Lundin KB, et al. (2004). Linkage between cryptorchidism, hypospadias, and 
GGN repeat length in the androgen receptor gene. J. Clin. Endocrinol. Metab. 89: 5105-5109.

Badran WA, Fahmy I, Abdel-Megid WM, Elder K, et al. (2009). Length of androgen receptor-CAG repeats in fertile and infertile Egyptian men. J. Androl. 30: 416-425.

Bogaert V, Vanbillemont G, Taes Y, De Bacquer D, et al. (2009). Small effect of the androgen receptor gene GGN repeat polymorphism on serum testosterone levels in healthy men. Eur. J. Endocrinol. 161: 171-177.

Castro-Nallar E, Bacallao K, Parada-Bustamante A, Lardone MC, et al. (2010). Androgen receptor gene CAG and GGN repeat polymorphisms in Chilean men with primary severe spermatogenic failure. J. Androl. 31: 552-559.

Choi JM, Chung P, Veeck L, Mielnik A, et al. (2004). AZF microdeletions of the Y chromosome and in vitro fertilization outcome. Fertil. Steril. 81: 337-341.

Crüger DG, Toft B, Agerholm I, Fedder J, et al. (2001). Birth of a healthy girl after ICSI with ejaculated spermatozoa from a man with non-mosaic Klinefelter's syndrome. Hum. Reprod. 16: 1909-1911.

Crüger DG, Agerholm I, Byriel L, Fedder J, et al. (2003). Genetic analysis of males from intracytoplasmic sperm injection couples. Clin. Genet. 64: 198-203.

Dadze S, Wieland C, Jakubiczka S, Funke K, et al. (2000). The size of the CAG repeat in exon 1 of the androgen receptor gene shows no significant relationship to impaired spermatogenesis in an infertile Caucasoid sample of German origin. Mol. Hum. Reprod. 6: 207-214.

Dowsing AT, Yong EL, Clark M, McLachlan RI, et al. (1999). Linkage between male infertility and trinucleotide repeat expansion in the androgen-receptor gene. Lancet 354: 640-643.

Ferlin A, Bartoloni L, Rizzo G, Roverato A, et al. (2004). Androgen receptor gene CAG and GGC repeat lengths in idiopathic male infertility. Mol. Hum. Reprod. 10: 417-421.

Gao T, Marcelli M and McPhaul MJ (1996). Transcriptional activation and transient expression of the human androgen receptor. J. Steroid Biochem. Mol. Biol. 59: 9-20.

Giovannucci E, Stampfer MJ, Krithivas K, Brown M, et al. (1997). The CAG repeat within the androgen receptor gene and its relationship to prostate cancer. Proc. Natl. Acad. Sci. U. S. A. 94: 3320-3323.

González A, Javier DF, Rodriguez G, Brito B, et al. (2007). Increased risk of breast cancer in women bearing a combination of large CAG and GGN repeats in the exon 1 of the androgen receptor gene. Eur. J. Cancer 43: 2373-2380.

Hakimi JM, Schoenberg MP, Rondinelli RH, Piantadosi S, et al. (1997). Androgen receptor variants with short glutamine or glycine repeats may identify unique subpopulations of men with prostate cancer. Clin. Cancer Res. 3: 1599-1608.

Hillmer AM, Hanneken S, Ritzmann S, Becker T, et al. (2005). Genetic variation in the human androgen receptor gene is the major determinant of common early-onset androgenetic alopecia. Am. J. Hum. Genet. 77: 140-148.

Hsing AW, Gao YT, Wu G, Wang X, et al. (2000). Polymorphic CAG and GGN repeat lengths in the androgen receptor gene and prostate cancer risk: a population-based case-control study in China. Cancer Res. 60: 5111-5116.

Katagiri Y, Neri QV, Takeuchi T, Moy F, et al. (2006). Androgen receptor CAG polymorphism (Xq11-12) status and human spermatogenesis: a prospective analysis of infertile males and their offspring conceived by intracytoplasmic sperm injection. Int. J. Mol. Med. 18: 405-413.

Komori S, Kasumi H, Kanazawa R, Sakata K, et al. (1999). CAG repeat length in the androgen receptor gene of infertile Japanese males with oligozoospermia. Mol. Hum. Reprod. 5: 14-16.

Lund A, Tapanainen JS, Lähdetie J, Savontaus ML, et al. (2003). Long CAG repeats in the AR gene are not associated with infertility in Finnish males. Acta Obstet. Gynecol. Scand. 82: 162-166.

Lundin KB, Giwercman A, Richthoff J, Abrahamsson PA, et al. (2003). No association between mutations in the human androgen receptor GGN repeat and inter-sex conditions. Mol. Hum. Reprod. 9: 375-379.

Lundin KB, Giwercman YL, Rylander L, Hagmar L, et al. (2006). Androgen receptor gene GGN repeat length and reproductive characteristics in young Swedish men. Eur. J. Endocrinol. 155: 347-354.

Martinez-Garza SG, Gallegos-Rivas MC, Vargas-Maciel M, Rubio-Rubio JM, et al. (2008). Genetic screening in infertile Mexican men: chromosomal abnormalities, Y chromosome deletions, and androgen receptor CAG repeat length. $J$. Androl. 29: 654-660.

Massart A, Lissens W, Tournaye H and Stouffs K (2012). Genetic causes of spermatogenic failure. Asian J. Androl. 14: 40-48.

Mengual L, Oriola J, Ascaso C, Ballesca JL, et al. (2003). An increased CAG repeat length in the androgen receptor gene in azoospermic ICSI candidates. J. Androl. 24: 279-284.

Mifsud A, Sim CK, Boettger-Tong H, Moreira S, et al. (2001). Trinucleotide (CAG) repeat polymorphisms in the androgen receptor gene: molecular markers of risk for male infertility. Fertil. Steril. 75: 275-281.

Patrizio P, Leonard DG, Chen KL, Hernandez-Ayup S, et al. (2001). Larger trinucleotide repeat size in the androgen receptor gene of infertile men with extremely severe oligozoospermia. J. Androl. 22: 444-448.

Poongothai J, Gopenath TS and Manonayaki S (2009). Genetics of human male infertility. Singapore Med. J. 50: 336-347. Rajpert-De Meyts E, Leffers H, Petersen JH, Andersen AG, et al. (2002). CAG repeat length in androgen-receptor gene 
and reproductive variables in fertile and infertile men. Lancet 359: 44-46.

Ruhayel Y, Lundin K, Giwercman Y, Hallden C, et al. (2004). Androgen receptor gene GGN and CAG polymorphisms among severely oligozoospermic and azoospermic Swedish men. Hum. Reprod. 19: 2076-2083.

Sasagawa I, Suzuki Y, Ashida J, Nakada T, et al. (2001). CAG repeat length analysis and mutation screening of the androgen receptor gene in Japanese men with idiopathic azoospermia. J. Androl. 22: 804-808.

Simoni M, Bakker E and Krausz C (2004). EAA/EMQN best practice guidelines for molecular diagnosis of y-chromosomal microdeletions. State of the art 2004. Int. J. Androl. 27: 240-249.

Tut TG, Ghadessy FJ, Trifiro MA, Pinsky L, et al. (1997). Long polyglutamine tracts in the androgen receptor are associated with reduced trans-activation, impaired sperm production, and male infertility. J. Clin. Endocrinol. Metab. 82: 3777-3782.

Tiepolo L and Zuffardi O (1976). Localization of factors controlling spermatogenesis in the nonfluorescent portion of the human Y chromosome long arm. Hum. Genet. 34: 119-124.

Van Assche E, Bonduelle M, Tournaye H, Joris H, et al. (1996). Cytogenetics of infertile men. Hum. Reprod. 11 (Suppl 4): $1-24$.

Van Golde R, Van Houwelingen K, Kiemeney L, Kremer J, et al. (2002). Is increased CAG repeat length in the androgen receptor gene a risk factor for male subfertility? J. Urol. 167: 621-623.

Viswambharan N, Suganthi R, Simon AM and Manonayaki S (2007). Male infertility: polymerase chain reaction-based deletion mapping of genes on the human chromosome. Singapore Med. J. 48: 1140-1142.

von Eckardstein S, Syska A, Gromoll J, Kamischke A, et al. (2001). Inverse correlation between sperm concentration and number of androgen receptor CAG repeats in normal men. J. Clin. Endocrinol. Metab. 86: 2585-2590.

Vutyavanich T, Piromlertamorn W, Sirirungsi W and Sirisukkasem S (2007). Frequency of Y chromosome microdeletions and chromosomal abnormalities in infertile Thai men with oligozoospermia and azoospermia. Asian J. Androl. 9: $68-75$.

Wallerand H, Rémy-Martin A, Chabannes E, Bermont L, et al. (2001). Relationship between expansion of the CAG repeat in exon 1 of the androgen receptor gene and idiopathic male infertility. Fertil. Steril. 76: 769-774.

Wang RX, Fu C, Yang YP, Han RR, et al. (2010). Male infertility in China: laboratory finding for AZF microdeletions and chromosomal abnormalities in infertile men from Northeastern China. J. Assist. Reprod. Genet. 27: 391-396.

Yoshida KI, Yano M, Chiba K, Honda M, et al. (1999). CAG repeat length in the androgen receptor gene is enhanced in patients with idiopathic azoospermia. Urology 54: 1078-1081. 